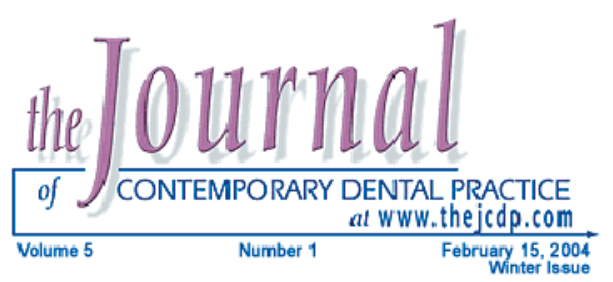

\title{
The Immediate Antimicrobial Effect of a Toothbrush and Miswak on Cariogenic Bacteria: A Clinical Study
}

\author{
Khalid Almas, BDS, MSc, FRACDS, FDSRCS Ed, DDPH, FICD
}

Zuhair Al-Zeid, BDS

$\nabla$

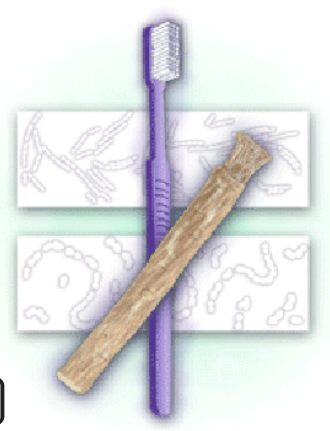

Abstract

The aim of this study was to assess the antimicrobial activity of the miswak chewing stick (Salvadora persica) in vivo, especially on streptococcus mutans and lactobacilli. The study was conducted clinically using patients' saliva and measuring the effect of miswak (chewing stick), miswak extract, toothbrush, and normal saline on mutans and lactobacilli. Forty male subjects aged 20-45 years were included in the study; there were four groups of ten subjects each. For the study, $50 \%$ of miswak extract (solution) was used. The levels of mutans streptococci and lactobacilli were measured using commercially available Vivacare line CRT (Caries Risk Test) bacteria 2 in 1 kit.

The results showed there was a marked reduction of streptococcus mutans among all groups. When the groups were compared, the reduction of streptococcus mutans was significantly greater using miswak in comparison to toothbrushing $(p=0.013)$, and there was no significant difference for lactobacilli reduction $(p=0.147)$. It may be concluded miswak has an immediate antimicrobial effect. Streptococcus mutans were more susceptible to miswak antimicrobial activity than lactobacilli.

Dietary intake of sugar and oral health status may be considered for controlled clinical trials with special emphasis on the antibacterial activity of miswak on cariogenic bacteria for a longer period of time. A toothbrush with and without toothpaste should be compared with miswak alone. Further research is needed with a larger sample size.

Keywords: Miswak (chewing stick), Salvadora persica, antimicrobial activity, cariogenic bacteria

Citation: Almas K, Al-Zeid Z. The Immediate Antimicrobial Effect of a Toothbrush and Miswak on Cariogenic Bacteria: A Clinical Study J Contemp Dent Pract 2004 February;(5)1:105-114.

(c) Seer Publishing 


\section{Introduction}

Oral hygiene measures have been practiced by different populations and cultures around the world since antiquity. Chewing sticks were used by the Babylonians some 7000 years ago; they were later used throughout the Greek and Roman empires and have been used by Jews, Egyptians, and Muslims. Today they are used in Africa, Asia, the Eastern Mediterranean region, and South America. ${ }^{1}$
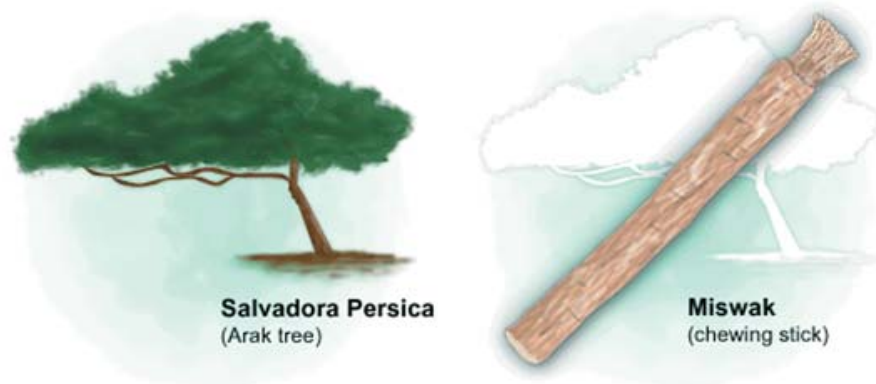

The most common source of miswak (chewing sticks) is Salvadora Persica, a small tree or shrub with a crooked trunk. The stems and roots of the plants are spongy and can easily be crushed between the teeth. Pieces of the root are usually scented and become soft when soaked in water. ${ }^{2}$

Several studies have reported on the antibacterial effects of chewing sticks on cariogenic bacteria and periodontal pathogens, particularly bacteroides species ${ }^{3-5}$ and inhibitory action on dental plaque formation. ${ }^{6}$ Recent studies on miswak have improved the understanding about various factors of miswak, e.g., age, size, thickness, and its freshness. ${ }^{7,8}$ The comparison of antimicrobial activity in aqueous and alcohol extracts has been made. ${ }^{9}$ However, a review of the literature has shown no previous investigation has assessed the comparative antimicrobial activity on salivary streptococcus mutans and lactobacilli using miswak and a toothbrush.
The aim of this study was to assess the antimicrobial activity of miswak extract, the use of a toothbrush alone, and saline on salivary streptococcus mutans and lactobacilli in vivo. This research project was registered and approved by the College of Dentistry Research Center (CDRC) ethical committee.

\section{Material and Methods}

\section{Preparation of Miswak Extract}

A sample of the most commonly used chewing sticks in Saudi Arabia, of which the color and scent indicated that it came from an Arak tree (Salvadora persica), was collected from Gizan province in Saudi Arabia.

The fresh miswak was cut into small pieces and allowed to dry at room temperature for two days. Then it was ground to powder in a ball mill. Successive 10 gram quantity was put into sterile screw-capped bottle to which $100 \mathrm{ml}$ of sterile deionized distilled water was added. The extract was allowed to soak for 48 hours at $4^{\circ} \mathrm{C}$ and then centrifuged at 2,000 rpm for 10 mins. The supernatant was passed through filter paper $(0.45 \mu \mathrm{m}$ pore size) and the extract was prepared at $50 \%$ concentration. The extract was stored at $4^{\circ} \mathrm{C}$ and used within one week. ${ }^{5}$

\section{Subject Selection}

Forty male subjects, 20-45 years of age, were selected from the periodontal clinics at King Saud University, College of Dentistry, Darriyah Campus. The selected subjects were medically healthy with no systemic diseases and had not used any antibiotics or antiseptic mouthwash during the last two weeks. Smokers were not included in the study.

The subjects were divided into four groups with 10 in each group.

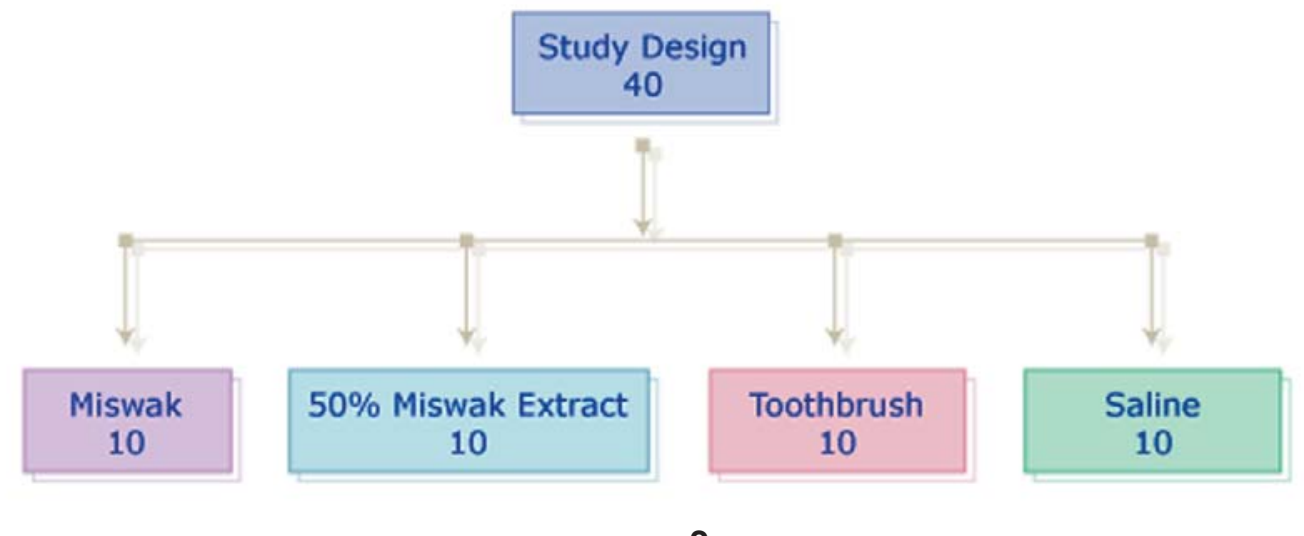

2

The Journal of Contemporary Dental Practice, Volume 5, No. 1, February 15, 2004 


\section{Group 1 - Miswak Group}

Ten subjects were asked to use fresh miswak for 6 minutes in clinic. A stimulated saliva sample $(2 \mathrm{ml})$ was collected before and after the use of miswak by expectorating into a sterile glass test tube.

\section{Group 2 - 50\% Miswak Extract (Solution)}

Ten subjects were asked to rinse with $50 \%$ miswak extract of $5 \mathrm{ml}$ for 6 minutes. A stimulated saliva $(2 \mathrm{ml})$ sample was collected before and after the use of the miswak extract (solution).

\section{Group 3 - Toothbrush}

Ten subjects were asked to brush their teeth with a new Colgate toothbrush (medium texture) for 6 minutes. A saliva sample was collected before and after toothbrushing.

\section{Group 4 - Saline (Control)}

Ten subjects were asked to rinse with normal saline $(5 \mathrm{ml})$ for 6 minutes. A $2 \mathrm{ml}$ stimulated saliva sample was collected before and after rinsing with saline.

\section{Collection of Saliva}

Stimulated saliva was collected at baseline and after use of the miswak extract, toothbrush, or saline.

The subjects were given a small piece of paraffin wax (1 cm long) and asked to chew for a period of 30 seconds then to swallow any saliva but not the paraffin. Thereafter, the subjects continued to chew the wax and saliva was collected at two minute intervals for a total period of six minutes. The accumulated saliva was used for subsequent tests.

\section{Salivary Levels of Mutans Streptococci and Lactobacilli}

The levels of mutans streptococci and lactobacilli were measured using commercial caries risk test, Vivacare line CRT (Caries Risk Test) bacteria 2 in 1 kit, (Vivadent, Liechtenstein/Europe). The kit is comprised of a slide attached to the cover of the vial. The commercial product had one side of the slide coated with a solid selective culture medium (mitis salivarius agar enriched with sucrose) for the cultivation of mutans streptococci, while the medium on the other side of the slide (Rogosa agar) was for the cultivation of lactobaccili. The salivary samples were used per the instructions of the manufacturer. The samples were incubated at $37^{\circ} \mathrm{C}$ for 48 hours. (Figure 1)

Growth density of the bacteria was evaluated under good lighting conditions by the naked eye and as per manufacturer's instructions. Bacterial growth was then scored by comparing with standards expressed in colony forming units (cfu) provided by the manufacturers as follows:

\section{Mutans Streptococci Scoring \\ $0=$ Very low colonies are detected \\ $1=$ Low, colonies growth are $<10^{5}$ cfu \\ $2=$ Medium, colonies growth are $>10^{5}$ but $<10^{6} \mathrm{cfu}$ \\ $3=$ High, colonies growth are $>10^{6} \mathrm{cfu}$ \\ Lactobacilli Scoring \\ $0=$ Very low colonies are detected \\ $1=$ Low, colonies are $\simeq 10^{3} \mathrm{cfu}$ \\ $2=$ Medium, colonies are $\simeq 10^{4} \mathrm{cfu}$ \\ $3=$ High, colonies are $\simeq 10^{5} \mathrm{cfu}$}

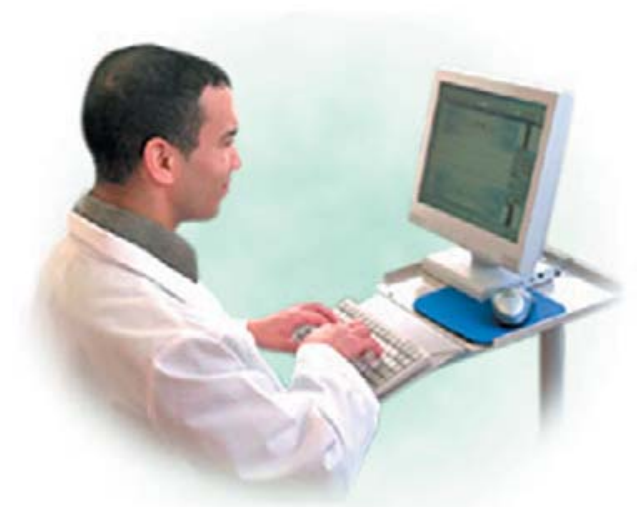

A pilot study was carried out to familiarize and standardized the procedure.

The data was entered using Fox Pro Software Program and analyzed by Statistical Package for Social Sciences (SPSS) version 10. Frequency distributions, mean, and standard deviations SD were generated. Kruskal-Wallis Test and Post Hoc Tukey Test were then used for comparison. The significance level was set at the 0.05 level. 


\section{Results}

The results showed there was a marked reduction of mutan streptococci after using different agents, i.e., miswak, 50\% miswak extract, toothbrush, and saline ranging from score 1 to 3 in different groups but the largest reduction was among the miswak group (Table 1).

In the miswak group $10 \%$ did not show any change, while $90 \%$ showed change in antibacterial activity. As far as reduction of lactobacilli was concerned, this was less as compared to mutans reduction (Table 2 ).

While comparing between the groups, miswak was significant in comparison to the toothbrush in reducing mutans $(p=0.013)$ (Figure 1$)$.

In group comparisons, there was no significant differences for lactobacilli reduction $(p=0.147)$ (Figure 2).

\section{Discussion}

The selection of miswak from the Salvadora persica tree for the present study was based on a number of factors. The use of miswak is most common in the Middle East region, its taste is not unpleasant, it is inexpensive, and has been reported to have anti-plaque and many pharmacological properties. ${ }^{10}$

The study for the bacterial count used the dipslide method ${ }^{11}$ for culturing both mutans streptococci and lactobacilli. The method is easy, simple, valid, and has been shown to be as accurate and reliable as the conventional culturing method. $^{12}$ (Figure 3)

Saliva was used for the bacterial count instead of plaque samples because saliva represents the oral load of the microorganism as well as their average colonization in the dentition. ${ }^{13,14,15}$ On the other hand, plaque samples represent only a

Table 1. Frequency distribution of mean difference of mutans among groups.

\begin{tabular}{|c|c|c|c|c|c|}
\hline \multirow[b]{2}{*}{ Group } & \multicolumn{4}{|c|}{ Difference in mutans } & \multirow[b]{2}{*}{$\begin{array}{l}\text { Total } \\
\text { n (\%) }\end{array}$} \\
\hline & $\begin{array}{c}3 \\
n(\%)\end{array}$ & $\begin{array}{c}2 \\
n(\%)\end{array}$ & $\begin{array}{c}1 \\
n(\%)\end{array}$ & $\begin{array}{c}0 \\
n(\%)\end{array}$ & \\
\hline 1. Miswak & $\begin{array}{c}2 \\
(20.0)\end{array}$ & $\begin{array}{c}3 \\
(30.0)\end{array}$ & $\begin{array}{c}4 \\
(40.0)\end{array}$ & $\begin{array}{c}1 \\
(10.0)\end{array}$ & $\begin{array}{c}10 \\
(100.0)\end{array}$ \\
\hline 2. Miswak extract & & $\begin{array}{c}2 \\
(20.0)\end{array}$ & $\begin{array}{c}8 \\
(80.0)\end{array}$ & & $\begin{array}{c}10 \\
(100.0)\end{array}$ \\
\hline 3. Toothbrush & & & $\begin{array}{c}5 \\
(50.0)\end{array}$ & $\begin{array}{c}5 \\
(50.0)\end{array}$ & $\begin{array}{c}10 \\
(100.0)\end{array}$ \\
\hline 4. Saline & & $\begin{array}{c}3 \\
(30.0)\end{array}$ & $\begin{array}{c}2 \\
(20.0)\end{array}$ & $\begin{array}{c}5 \\
(50.0)\end{array}$ & $\begin{array}{c}10 \\
(100.0)\end{array}$ \\
\hline Total & $\begin{array}{c}2 \\
(5.0)\end{array}$ & $\begin{array}{c}8 \\
(20.0)\end{array}$ & $\begin{array}{c}19 \\
(47.5)\end{array}$ & $\begin{array}{c}11 \\
(27.5)\end{array}$ & $\begin{array}{c}40 \\
(100.0)\end{array}$ \\
\hline
\end{tabular}

Note: $0=$ no change, 1,2 , and 3 indicates the magnitude of change.

Table 2. Frequency distribution of mean difference of lactobacilli among groups.

\begin{tabular}{|l|c|c|c|c|}
\hline \multirow{2}{*}{ Group } & \multicolumn{3}{|c|}{ Difference in Lactobacilli } & \multirow{2}{*}{ Total } \\
\cline { 2 - 5 } & $\begin{array}{c}2 \\
\mathrm{n}(\%)\end{array}$ & $\begin{array}{c}1 \\
\mathrm{n}(\%)\end{array}$ & $\begin{array}{c}0 \\
\mathrm{n}(\%)\end{array}$ & $\mathrm{n}(\%)$ \\
\hline 1. Miswak & 2 & 7 & $(10.0) 1$ & 10 \\
$(20.0)$ & $(70.0)$ & $(100.0)$ \\
\hline 2. Miswak extract & 1 & 8 & 1 & 10 \\
& $(10.0)$ & $(80.0)$ & $(10.0)$ & $(100.0)$ \\
\hline 3. Toothbrush & 1 & 8 & 1 & 10 \\
4. Saline & $(10.0)$ & $(80.0)$ & $(10.0)$ & $(100.0)$ \\
\hline Total & & 6 & 4 & 10 \\
& & $(60.0)$ & $(40.0)$ & $(100.0)$ \\
\hline
\end{tabular}




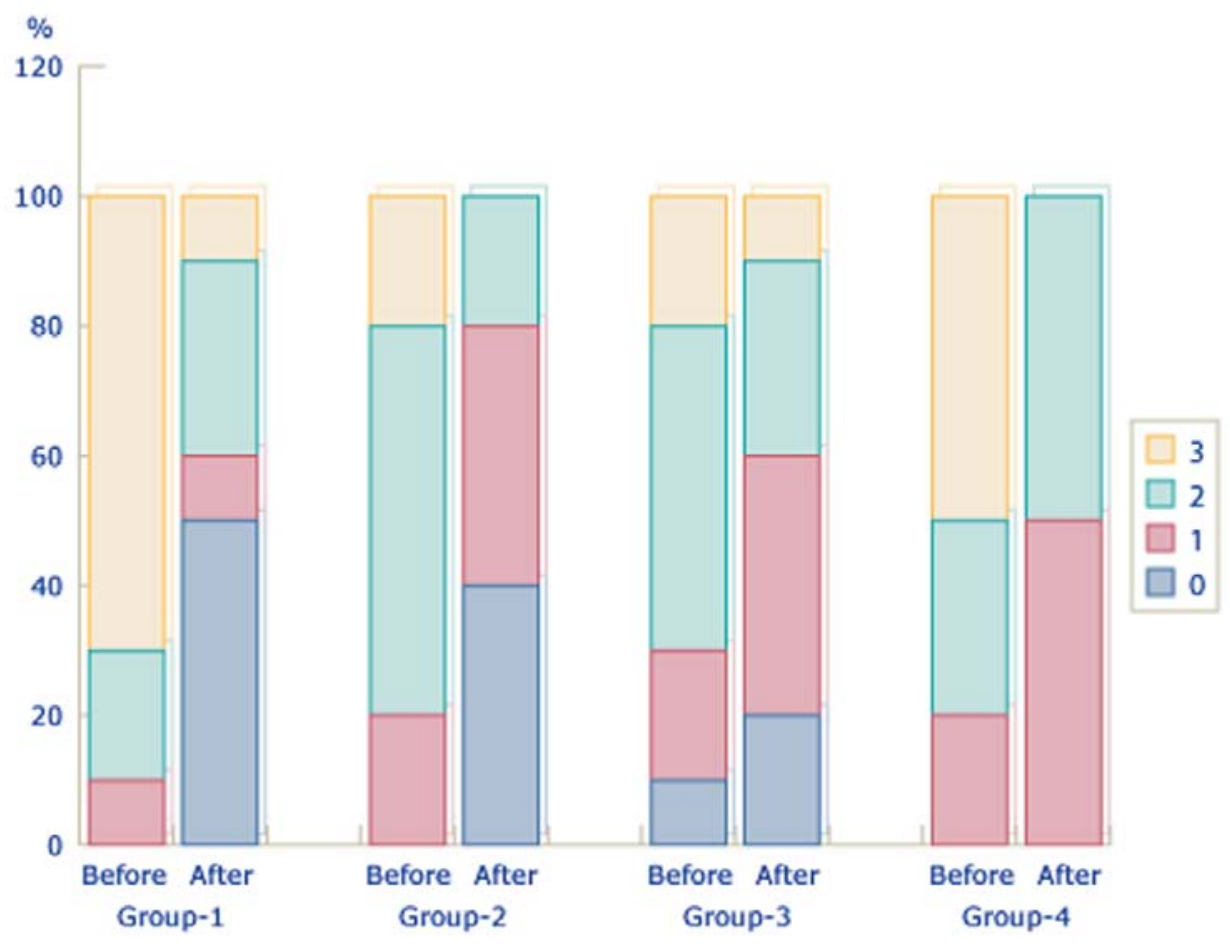

Figure 1. Percentage difference of subjects with streptococcus mutans before and after use of various agents.

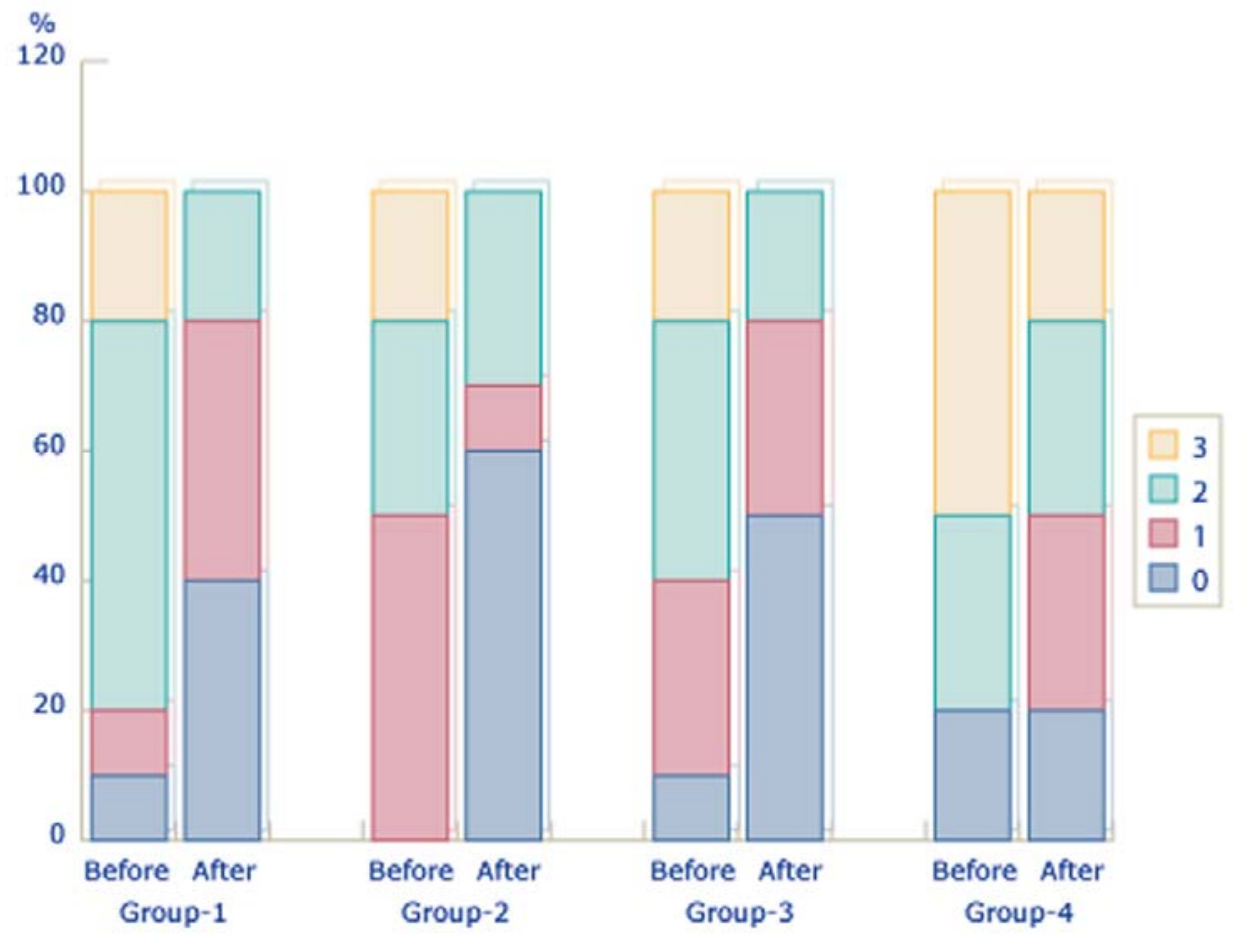

Figure 2. Percentage difference of subjects with Lactobacilli before and after use of various agents. 


\section{$\mathrm{CRT}^{\circledR}$ bacteria}
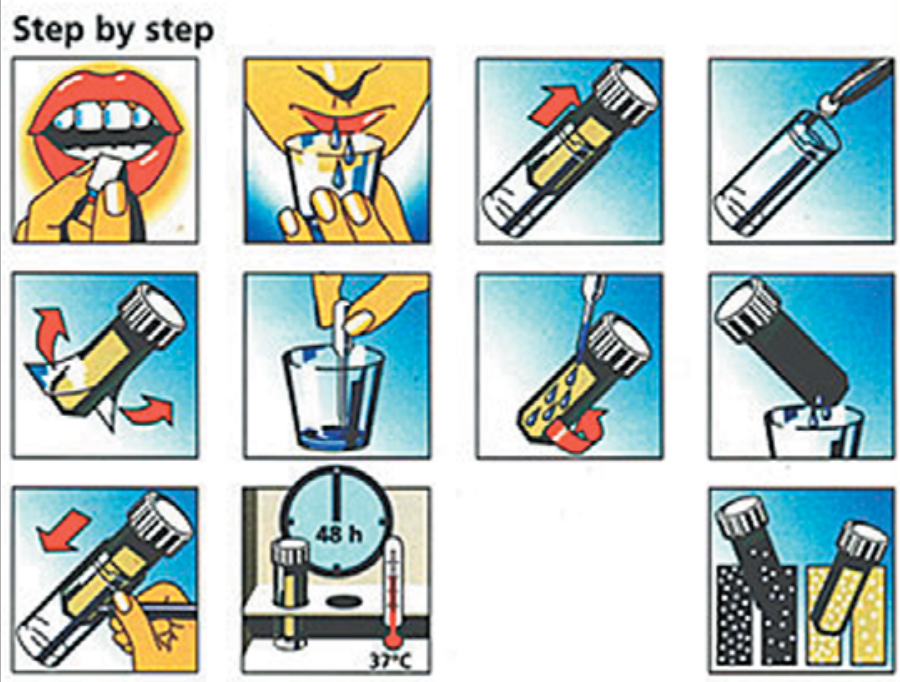

Figure 3. Vivacare line CRT (Caries Risk Test) bacteria 2 in 1 kit. (Courtesy, Vivadent, Liechtenstein.)

single site, and there is a wide variation in bacterial numbers among different tooth surfaces. ${ }^{16}$ In addition, the collection of the plaque mass is difficult, time consuming, and one can easily miss a key area when collecting the samples. ${ }^{17}$

In the present study, there was significant immediate reduction in streptococcus mutans while comparing miswak with toothbrushing. There was no significant difference in lactobacilli count among the four different groups. This may be due to the amount of lactobacilli present in saliva at the time of collection.

There are studies on the comparison of toothbrushes and miswak for plaque removal, but so far no data are available on salivary bacterial

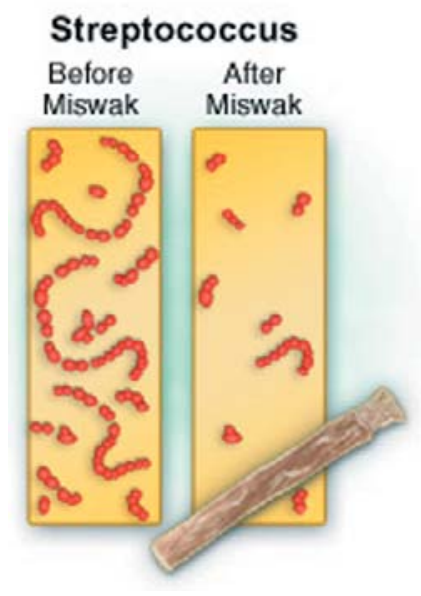

count reductions by using the dip-slide method along with the use of miswak with a toothbrush. Low dental caries among miswak users has been reported in epidemiological studies. In a dental health survey in the Sudan, Emslie ${ }^{18}$ reported for the first time there are fewer caries in people using chewing sticks than in those using toothbrushes. Low caries prevalence among chewing stick users has been reported despite the intake of a carbohydrate - rich diet and lack of modern dental prophylactic measures. ${ }^{19,20}$ In general, the Namibian muthala users had a relatively low caries rate. ${ }^{21}$ In a study from Zimbabwe, it was found children who used chewing sticks for oral hygiene had fewer caries lesions than children who brushed their teeth with a conventional toothbrush and paste. ${ }^{22}$ The in vivo cariogenic salivary bacterial count reduction may be considered an explanation for the above mentioned epidemiological studies on miswak and dental caries.

The therapeutic and prophylactic effects of chewing sticks may be due to mechanical cleaning, the potential release of biologically active chemicals when used, and/or a combination of both. The substantial amount of silica detected in S. persica ashes has been suggested to contribute to miswak's mechanical action in plaque removal. ${ }^{22}$ However, literature regarding the mechanical cleansing efficacy of miswak, as compared to the 
manual or electric toothbrushes, has been quite scarce. Current studies available frequently lack specific details concerning the time, duration, and frequency of their use which prevents meaningful assessments of the mechanical cleaning effect of miswak upon oral health. ${ }^{23}$ As the chewing stick is often left in the mouth for some time post cleansing, the enhanced salivation may also promote better cleansing and thus maintenance of oral health. ${ }^{24}$

In a recent study ${ }^{25}$ to determine whether use of miswak as a toothbrush affects the proportion of streptococci present on the tooth surface, 30 volunteers were instructed to use a commercially prepared miswak twice daily for 14 days as an adjunct to their normal oral hygiene practice. It was found that six of the participants $(20 \%)$ experienced a decrease in the proportion of total mutans streptococci of more than two orders of magnitude which was restored after cessation of miswak use.

\section{Conclusion}

Within the confines of the present study, the following conclusions can be drawn:

1. The clinical study showed there was a reduction in microbial count by all agents used in different groups.

2. Miswak extract $(50 \%)$ demonstrated antimicrobial activity. (reduction in bacterial count).

3. Streptococcus mutans counts were reduced more through the use of miswak than by using a conventional toothbrush in salivary bacterial counts.

4. Lactobacilli reduction was not significant in group comparisons.

It is recommended further research should be carried out on a larger sample size. Salivary bacterial count, dietary intake of sugar, and oral health status may also be considered. Controlled clinical trials are needed to find out the effect of Salvadora persica on cariogenic microorganisms in comparison with a toothbrush, with and without fluoride toothpaste, for a prolonged period of time to assess the substantivity of the tested material. Controlled clinical trials are needed to determine the substantivity effect of Salvadora persica (miswak) rather than the washing effect on cariogenic microorganisms. Further work is needed for comparison of the toothbrush, with and without toothpaste, and miswak because miswak contains both chemical and mechanical factors. 


\section{References}

1. Lewis WW, Lewis ME. Mecial Botany - Willy Inter Science Publications. London 1977.

2. Almas K, Al-Lafi TR. The natural toothbrush. World Health Forum. 1995;16(2):206-10. No abstract available.

3. Wolinsky LE, Sote EO. Inhibiting effect of aqueous extracts of eight Nigerian chewing sticks on bacterial properties favouring plaque formation. Caries Res. 1983;17(3):253-7. No abstract available.

4. Sote EO, Wilson M. In-vitro antibacterial effects of extracts of Nigerian tooth-cleaning sticks on periodontopathic bacteria. Afr Dent J. 1995;9:15-9.

5. Al-Lafi T, Ababneh $\mathrm{H}$. The effect of the extract of the miswak (chewing sticks) used in Jordan and the Middle East on oral bacteria. Int Dent J. 1995 Jun;45(3):218-22.

6. Wolinsky LE, Mania S, Nachnani S, et. al. The inhibiting effect of aqueous Azadirachta indica (Neem) extract upon bacterial properties influencing in vitro plaque formation. J Dent Res. 1996 Feb;75(2):816-22.

7. Almas $\mathrm{K}, \mathrm{Al}-\mathrm{Bagieh} \mathrm{NH}$, Akpata ES. In vitro antimicrobial effects of extracts of freshly cut and 1month old miswak (chewing sticks). Biomedical Letters 1997;56:145-49.

8. Almas K, Al-Bagieh $\mathrm{NH}$. The antimicrobial effects of bark and pulp extracts of miswak, Salvadora persica. Biomedical Letter 1999;60:71-75.

9. Al-Bagieh $\mathrm{NH}$, Almas K. In vitro antibacterial effects of aqueous and alcohol extracts of miswak (chewing sticks). Cairo Dent J 1997;13:221-24.

10. Lewis ME. Plants and dental health. J Preventive Dentistry 1980;6:75-80.

11. Larmas M. A new dip-slide method for the counting of salivary lactobacilli. Proc Finn Dent Soc. 1975 Apr;71(2):31-35. No abstract available.

12. Jordan HV, Laraway $R$, Snirch $R$, et. al. A simplified diagnostic system for cultural detection and enumeration of Streptococcus mutans. J Dent Res. 1987 Jan;66(1):57-61.

13. Köhler B, Pettersson BM, Bratthall D. Streptococcus mutans in plaque and saliva and the development of caries. Scand J Dent Res. 1981 Feb;89(1):19-25.

14. Emilson CG. Prevalence of streptococcus mutans with different colonial morphologies in human plaque and saliva. Scand J Dent Res. 1983 Feb;91(1):26-32.

15. Brown JP. Developing clinical teaching methods for caries risk assessment: introduction to the topic and its history. J Dent Educ. 1995 Oct;59(10):928-31. No abstract available.

16. Lindquist B, Emilson CG. Distribution and prevalence of mutans streptococci in the human dentition. J Dent Res. 1990 May;69(5):1160-6.

17. Leverett DH, Featherstone JD, Proskin HM, et. al. Caries risk assessment by a cross-sectional discrimination model. J Dent Res. 1993 Feb;72(2):529-37.

18. Emslie RD. A dental health survey in the Republic of the Sudan. Br Dent J. 1966 Feb 15;120(4): 167-78. No abstract available.

19. Carl W, Zambon JJ. Dental health of the Rendille and Samburu of the northern frontier district of Kenya. N Y State Dent J. 1993 Jun-Jul;59(6):35-9.

20. Elvin-Lewis M, Hall JB, Adu-tutu M, et. al. The dental health of chewing stick users of Southern Ghana; preliminary findings. J Prev Dent 1980;6:151-159.

21. Shier M, Cleaton-Jones P. Dental caries in Namibia--the first national survey. Community Dent Oral Epidemiol. 1995 Oct;23(5):262-5. No abstract available.

22. Sathananthan K, Vos T, Bango G. Dental caries, fluoride levels and oral hygiene practices of school children in Matebeleland South, Zimbabwe. Community Dent Oral Epidemiol. 1996 Feb;24(1):21-4.

23. Hardie J, Ahmed K. The Miswak as an aid in oral hygiene. J Philipp Dent Assoc. 1995 JunAug;47(1):33-8.

24. Wu CD, Darout IA, Skaug N. Chewing sticks: timeless natural toothbrushes for oral cleansing. J Periodontal Res. 2001 Oct;36(5):275-84. Review.

25. Elhably BM, Dolheguy MR, Tompkins GR. The effect of miswak (Salvadora persica) use on oral streptococci. 2001 (personal communication) University of Otago, Dunedin, New Zealand. 


\section{About the Authors}

\section{Khalid Almas, BDS, MSc, FRACDS, FDSRCS Ed, DDPH, FICD}

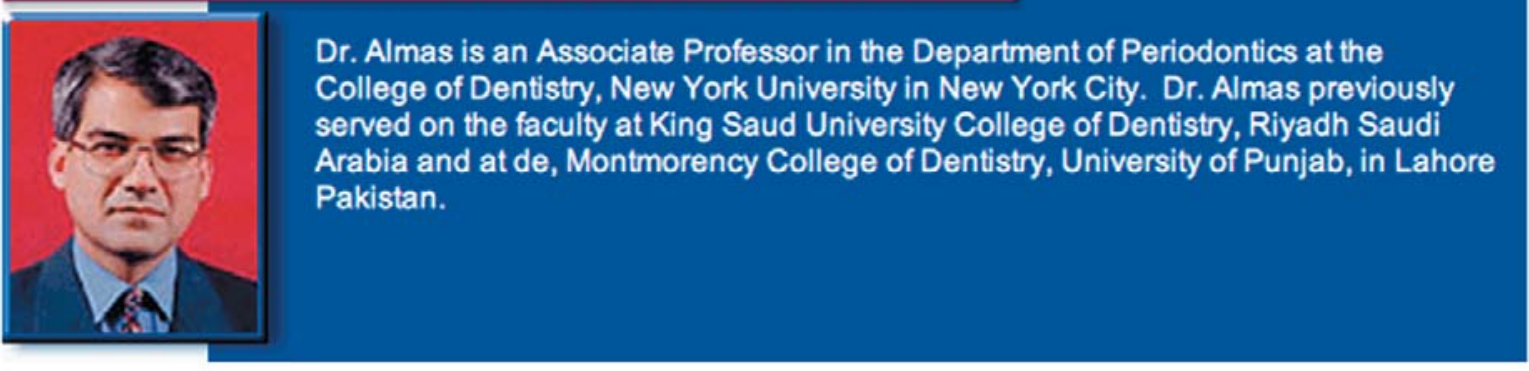

\section{Zuhair AI-Zeid, BDS}

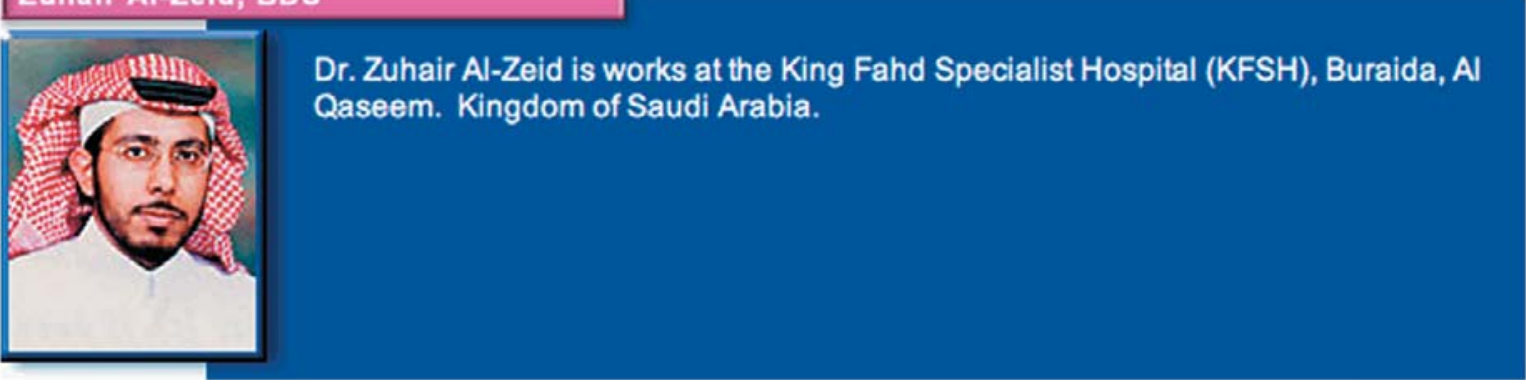

\section{Acknowledgment}

The authors would like to thank all those subjects who participated in the study. Mr. Ibrahim from Microbiology Laboratory, King Saud University, College of Dentistry for his help in laboratory procedures. Thanks to Dr. Nazeer Khan for his help in data analysis. The study was supported by College of Dentistry Research Center, CDRC-NF \#1830. 